\title{
Green Synthesis and Antibacterial Activities of Silver Nanoparticles Using Extracellular Laccase of Lentinus edodes
}

\author{
Agbaje LATEEF*, Adeyemi Ojutalayo ADEEYO \\ Ladoke Akintola University of Technology, Department of Pure and Applied Biology, Microbiology Unit, PMB 4000, Ogbomoso, \\ Nigeria; alateef@lautech.edu.ng( ${ }^{*}$ correspondingauthor)
}

\begin{abstract}
This study reports the multi-step mutagenesis of Lentinus edodes towards optimization of the production of laccase and novel application of laccase in the biosynthesis of silver nanoparticles (AgNPs) which could be used to develop an eco-friendly method for the rapid biosynthesis of AgNPs. The wild strain of $L$. edodes was subjected to UV irradiation at $254 \mathrm{~nm}$ and the resultant viable mutant was further treated with acridine orange, a chemical mutagen. The strains were evaluated for the production of laccase and the crude laccase of the UV mutant $\left(U_{10}\right)$ was used for the green synthesis of AgNPs. The particles were characterized by UV-Visible spectroscopy, Fourier transform infrared (FTIR) spectroscopy and scanning electron microscopy $(\mathrm{SEM})$. Laccase activities of wild, $\mathrm{UV}_{10}$ and $\mathrm{UV}_{10} \mathrm{ACR}_{8}$ strains of $L$. edodes were obtained as $2.6,10.6$ and $2.8 \mathrm{U} / \mathrm{ml} / \mathrm{min}$ respectively after 7 days of fermentation, showing laccase yield improvement of 4.08-fold for $U_{10}$ mutant. UV-Visible spectroscopy indicated the formation of AgNPs at absorption band of $430 \mathrm{~nm}$. FTIR result indicated that proteins were responsible for AgNP synthesis, while SEM analysis confirmed the formation of walnut-shaped nanoparticles with size range of 50-100 nm. The biosynthesized nanoparticles revealed effective inhibition against clinical isolates of Escherichia coli, Pseudomonas aeruginosa and Klebsiella pneumoniae. To the best of the authors' knowledge, this result represents the first report on the biosynthesis of AgNPs using L. edodes metabolite. The report adds to the growing relevance of $L$. edodes as potential industrially viable organism, used for diverse biotechnological applications.
\end{abstract}

Keywords: Lentinus edodes, silver nanoparticles, green synthesis, mutagenesis, antibacterial activities, laccase

\section{Introduction}

Nanobiotechnology is defined as the aspect of biotechnology that deals with synthesis, design and stabilization of various nanoparticles using biological tools (Shaligram et al., 2009; Lateef $e t$ al., 2015a). It involves manipulation of particles structure with dimension smaller than $100 \mathrm{~nm}$. Nanoparticles have been classically produced by physical and chemical methods (Guzman et al., 2012) involving techniques like heating (Huang and Yang, 2004) and irradiation (Abid et al., 2002; Gasaymeh et al., 2010). However, these methods are costly, toxic and hazardous (Mohamed, 2013; Lateef et al., 2015a), hence the need for alternative, eco-friendly approaches, which may be assured by biological methods. Biological methods of synthesis of nanoparticles have shown very promising solutions to those posed by classical approaches. Green synthesis of AgNPs using diverse biological materials such as spider cobweb, Cola nitida (Kolanut) seed, seed shell, pod and cell-free extract of Bacillus safensis with potent biological activities was recently demonstrated (Lateef et al., 2015b,c).

Myconanotechnology is the interface of mycology and nanotechnology, involving the use of fungi in the biosynthesis of metal nanoparticles (Mukherjee, 2002; Lloyd, 2003; Rai et al., 2009). Extracts like amino acids, polysaccharides, vitamins and enzymes, as well as whole cells of plants, yeasts, bacteria and fungi have been used to mediate synthesis of nanoparticles (Kalimuthu et al., 2008; Acosta, 2009; Philip, 2009; Tripathy et al., 2010; Lateef et al., 2015c). Fungi are preferred mediators of nanoparticles synthesis because they are easy to handle, require simple nutrients and possess high wall-binding capacity, as well as intracellular metal uptake capabilities (Sanghi and Verma, 2009).

Metals like copper, zinc, titanium (Schabes-Retchkiman et al., 2006), magnesium, gold (Gu et al., 2003) and silver had come up for synthesis of nanoparticles (Mohamed, 2013). Silver nanoparticles have been reportedly used in treatment of burns, as dental materials, textile fabrics, water treatment and sunscreen lotions (Duran et al., 2007). Silver nanoparticles have applications in the production of antimicrobial paints (Kumar et al., 2008), non-linear optics, spectrally selective coatings for solar energy adsorption and intercalation materials for electrical batteries, optical receptors, catalyst of chemical reactions, biolabelling and antibacterial agents (Durán et al., 2005). Nanoparticles have also been used in nanoscaffolds to regenerate central nervous system cells (Ellis-Behnke, 2006), bio-separation membranes (Martin and Kohli, 2003), drug delivery to target organs (Uhrich et al., 1999), gene transfection (Kneuer et al., 2000), medical imaging (Harisinghani et al., 2003), nucleic acid sequence and protein detection, nanophase extractors (Martin and Kohli, 2003) and treatment of local 
406

anaesthetic toxicity. In addition, silver nanoparticles have proved very effective as good antimicrobial agent against bacteria, viruses and other eukaryotic microorganisms (Gong et al., 2007; Lara et al., 2010).

Lentinus edodes is one of the choice edible mushrooms which can be cultivated in a warm moist climate. It occurs naturally throughout Southeast Asia and has been reported in China, Japan, Korea, Vietnam, Thailand, Burma, North Borneo, Philippines, Taiwan and New Guinea. The geographic distribution of shiitake in nature extends beyond Northeast Asia, but the exact limits are uncertain (Bisen et al., 2010). Lentinus spp. have been used by people all over the world for their nutritional value, medicinal properties and other beneficial effects (Barros et al., 2008; Thillaimaharani et al., 2013; Finimundy et al., 2014). In this work, a multi-step mutagenesis of L. edodes towards optimization of the production of laccase was undertaken, and the novel application of laccase in the biocatalysis of silver nanoparticles synthesis was demonstrated. The ability of the biosynthesized nanoparticles to inhibit pathogenic bacterial strains was also investigated.

\section{Materials and Methods}

\section{Fungalstrain}

A pre-identified wild strain of $L$. edodes was obtained from Mushroom Research Centre, Solan, Himachal Pradesh, India. The culture was maintained by sub-culturing monthly and stored at $4^{\circ} \mathrm{C}$ on potato dextrose agar (PDA) slants to maintain viability.

\section{Generation of mutant strains}

The process of mutagenesis was carried out by exposing a 14-day actively growing culture of the wild fungus on PDA plate $(90 \mathrm{~mm})$ to ultraviolet irradiation $(254 \mathrm{~nm}, 15 \mathrm{~cm})$ for 5 , $10,15,20,25,30,45,60,75$ and 90 min. Mutants were immediately sub-cultured and incubated in the dark at $25 \pm 2$ ${ }^{\circ} \mathrm{C}$ for 14 days (Adebayo et al., 2012). Based on improved exopolysaccharide (EPS) productivity (Dubois et al., 1956), a viable mutant obtained at $10 \mathrm{~min}$ of ultraviolet irradiation $\left(\mathrm{UV}_{10}\right)$ was selected and subsequently exposed to chemical mutagenesis in $7.81 \times 10^{-5} \mathrm{~g} / \mathrm{ml}$ of acridine orange $(\mathrm{BDH}$ Chemicals Ltd, Poole, England) suspended in potato dextrose broth (PDB) (Toh-e and Wickner, 1981). The culture was incubated at $25 \pm 2{ }^{\circ} \mathrm{C}$ for $72 \mathrm{~h}$ after which the strain was reintroduced onto freshly prepared PDA slant and incubated for 14 days to obtain fully ramified acridine mutant strain $\mathrm{UV}_{10} \mathrm{ACR}_{8}$. The wild, $\mathrm{UV}_{10}$ and $\mathrm{UV}_{10} \mathrm{ACR}_{8}$ strains generated were reassessed for quality improvement and used for the production of laccase. laccase

Fermentation medium and conditions for the production of

Cultures of wild and mutant strains of $L$. edodes were inoculated into $250 \mathrm{ml}$ fermentation medium obtained based on five media factors (Nehad and El-Shammy, 2010) containing: glucose $(40.0 \mathrm{~g} / \mathrm{L})$, yeast extract $(1.1 \mathrm{~g} / \mathrm{L})$, peptone $(2.0 \mathrm{~g} / \mathrm{L})$, $\mathrm{KH}_{2} \mathrm{PO}_{4}(2.0 \mathrm{~g} / \mathrm{L}), \mathrm{MgSO}_{4}(1.7 \mathrm{~g} / \mathrm{L})$ at $\mathrm{pH}$ 5.5. The cultures were incubated at $25 \pm 2{ }^{\circ} \mathrm{C}$ at $100 \mathrm{rpm}$ for 7 days. After seven days of cultivation, laccase was obtained by sieving broth cultures of the respective strains through Whatman No 1 filter paper and centrifuged at $4,000 \mathrm{rpm}$ for $15 \mathrm{~min}$ at $10{ }^{\circ} \mathrm{C}$. The resultant filtrate was collected as crude enzyme fraction and used for further studies.

\section{Laccase assay}

Laccase activity was determined using the method of Ride (1980). Reaction mixtures consisted of $0.5 \mathrm{ml}$ of the enzyme, 2.2 $\mathrm{ml}$ of phosphate buffer $(0.2 \mathrm{M})$ and $0.3 \mathrm{ml}$ of $0.01 \%$ syringaldehyde (Sigma-Aldrich, Germany) which was dissolved in absolute ethanol. The absorbance of the reaction mixture was determined at $530 \mathrm{~nm}$ on a spectrophotometer (Genesys $10 \mathrm{UV}$, Thermoelectron Corporation, UK) immediately and after $10 \mathrm{~min}$ of reaction. The change in absorbance was then obtained and used to calculate the laccase activities of wild, $\mathrm{UV}_{10}$ and $\mathrm{UV}_{10} \mathrm{ACR}_{8}$ strains of $L$. edodes.

The enzyme activity was obtained as follows:

$$
\text { Unit per ml of enzyme }=\frac{\text { Change in } \mathrm{A} 530 \mathrm{~nm} \text { Per min Test }- \text { Change in } \mathrm{A} 530 \mathrm{~nm} \text { Blank }}{0.01(0.5)} \times \text { Dillution Factor }
$$

One unit of laccase enzyme will produce a change in absorbance of 0.01 at $530 \mathrm{~nm}$ per min at $\mathrm{pH}$ of 5.7 and room temperature in $3 \mathrm{ml}$ reaction volume using syringaldehyde as substrate.

\section{Laccase-mediated synthesis and characterization of silver nanoparticles (AgNPs)}

AgNPs were synthesized by reacting crude laccase of $U_{10}$ which had the highest laccase activity with $1 \mathrm{mM}$ silver nitrate solution as described by Lateef et al. (2015a). About $12 \mathrm{ml}$ of crude laccase enzyme of respective strain was dispensed into reaction vessel containing $30 \mathrm{ml}$ of $1 \mathrm{mM}$ silver nitrate $\left(\mathrm{AgNO}_{3}\right)$ for the green synthesis of AgNPs. A control containing $42 \mathrm{ml}$ of silver nitrate in a separate reaction vessel was also set up. The reaction was investigated at room temperature $\left(28 \pm 2^{\circ} \mathrm{C}\right)$ with intermittent shaking. The development of colour as a result of formation of AgNPs was monitored visually, while the absorbance spectrum of the reaction mixture was measured using a UV-visible spectrophotometer (Genesys 10 UV, Thermoelectron Corporation, UK). The Fourier transform infrared (FTIR) spectroscopic analysis of the dried nanoparticles was carried out using $\mathrm{KBr}$ pellets on a spectrophotometer (BUCK Scientific M530, BUCK Corporation, USA) to identify the possible biomolecules responsible for the synthesis of nanoparticles. The morphology of the biosynthesized nanoparticles was elucidated through scanning electron microscopy. Scanning electron images were collected using an ASPEX 3020 in bright field mode at an accelerating voltage of $15 \mathrm{kV}$.

\section{Antibacterial activities of the biosynthesized silver nanoparticles}

The antibacterial test was carried out using agar disc diffusion method as described by Lateef $e t$ al. (2015a). A total of ten clinical bacterial isolates including three strains of Escherichia coli, Klebsiella spp. and Pseudomonas aeruginosa and a strain of Staphylococcus aureus (obtained from the culture bank of Microbiology Unit, Department of Pure and Applied Biology, Ladoke Akintola University of Technology, Nigeria) were used in this study. Paper disc of $6 \mathrm{~mm}$ diameter was prepared from Whatman No. 1 filter paper. The bacteria suspension used was standardized by picking a loopful of the bacteria and suspending in $10 \mathrm{ml}$ sterile saline water. This was used to make subsequent 10 fold dilutions from which $0.1 \mathrm{ml}$ amount was added to $4 \mathrm{ml}$ amount of nutrient agar at $50^{\circ} \mathrm{C}$. This was poured on plates of basal medium and left alone to solidify. The paper discs were impregnated with nanoparticles solutions (dispersion in water) of 
Table 1. Laccase activities of wild and mutant strains of $L$. edodes

\begin{tabular}{lcc}
\hline Strain & $\begin{array}{c}\text { Laccase activity } \\
(\mathrm{U} / \mathrm{ml})\end{array}$ & $\begin{array}{c}\text { Fold improvement relative to } \\
\text { the wild strain }\end{array}$ \\
\hline $\mathrm{Wild}$ & 2.6 & - \\
$\mathrm{UV}_{10}$ & 10.6 & 4.08 \\
$\mathrm{UV}_{10} \mathrm{ACR}_{8}$ & 2.8 & 1.08 \\
\hline
\end{tabular}

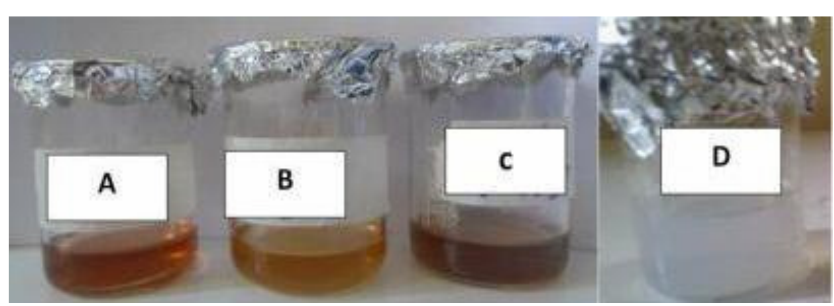

Fig. 1. Colour formation during the synthesis of AgNPs after $1 \mathrm{~h}$ of reaction (A-wild; $\mathrm{B}-\mathrm{UV}_{10} ; \mathrm{C}-\mathrm{UV}_{10} \mathrm{Acr} ; \mathrm{D}$ - control)

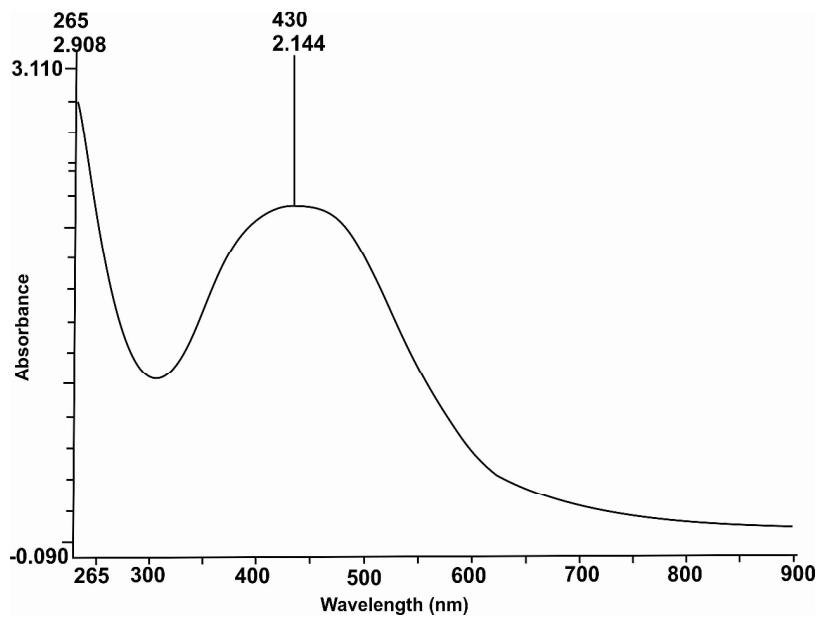

Fig. 2. UV-Vis absorption spectrum of the biosynthesized AgNPs using laccase of $U V_{10}$ strain of $L$. edodes

$\mathrm{UV}_{10}$ and placed on bacteria lawn after solidification. Zones of inhibitions were observed and measured after incubation at $37^{\circ} \mathrm{C}$ for $18 \mathrm{~h}$.

\section{Results}

Effect of mutagenesis on laccase production by the wild, $U V_{10}$ and $U V_{10} A C R_{8}$ strains of L. edodes

Laccase activities of wild, $\mathrm{UV}_{10}$ and $\mathrm{UV}_{10} \mathrm{ACR}_{8}$ strains of $L$. edodes were recorded as 2.6, 10.6 and $2.8 \mathrm{U} / \mathrm{ml} / \mathrm{min}$ respectively, after 7 days of fermentation (Table 1). The enzyme activity was in the following order: $U_{10}>U V_{10} A_{C R}$ $>$ wild, showing improvement in the laccase activities of the generated mutants over the wild strain. The data obtained in the hereby study were higher than that of Kumar and Srikumar (2010), which reported an activity of $2.8 \times 10^{-4} \mathrm{U} / \mathrm{ml}$ for laccase from Opuntia vulgaris and $1.75 \mathrm{U} / \mathrm{ml}$, as well as than the result of $2.5 \mathrm{U} / \mathrm{ml}$ obtained for the wild and mutant strains of Pleurotus pulmonarius respectively by Adebayo et al. (2012).

The production level achieved in the current study was however similar to the laccase activity of $11.3 \mathrm{U} / \mathrm{ml}$ by $L$. edodes when ATBS substrate was used by Makkar et al. (2001). Though there is limited information on laccase activities of $L$. edodes (Cavallazzi et al., 2004; Morozova et al., 2007), laccase productivity reported in this work supports the application of mushrooms in extracellular synthesis of laccases (Leonowicz et al., 2001; Makkar et al., 2001; Claus, 2004; Strong, 2011; Dhakar and Anita, 2013; Fonseca et al., 2013). Several applications of mushrooms and laccases have been reported for degradation of recalcitrant environmental pollutants (Couto and Herrera, 2006), detoxification of industrial effluents of textile and petrochemical industries (Kuhad et al., 1997; Abadulla et al., 2000; Hou et al., 2004; Couto et al., 2005), medical diagnostics and cleaning up of pesticide and explosives (Duran and Esposito, 2000). Therefore, laccases have lots of industrial applications in the biodegradation of pollutants, design of biosensors to detect phenols in wastewater and the development of biofuel cells (Fernández-Fernández et al., 2013).

\section{Biosynthesis and characterization of silver nanoparticles}

There are limited reports on the use of metabolites of $L$. edodes in the production of nanoparticles, as only two reports for its usage in the synthesis of gold nanoparticles were reported till date (Vetchinkina et al., 2013, 2014). Some works have demonstrated the formation of gold nanoparticles (Faramarzi and Forootanfar, 2011; Sanghi et al., 2011; El-Batal et al., 2015) and silver nanoparticles using fungal laccases (Durán et al., 2014, 2015). However, in this study, crude laccase from $L$. edodes was used to synthesize AgNPs.

The AgNPs were characterized with typical yellowishbrown colour produced from the bio-reduction of silver ions by the enzyme. The intensity of colour increased as the bioreduction of silver ions progressed and stabilized when the reaction was completed. Fig. 1 shows the colour development during the biosynthesis of the AgNPs.

Typical AgNPs colouration, previously reported from bacterial exopolysccharides and mushroom culture extracts and mycelia, was yellowish brown for Lactobacillus rhamnosus (Kanmani and Lim, 2013), yellow for Pleurotus ostreatus, Agaricus bisporus and Ganoderma lucidum, reddish brown for Calocybe indica, light-grey for Schizophyllum comune and dark brown for Stachybotrys chartarum (Mohamed, 2013). The variation in colour is attributed to the variation in composition of biomolecules involved in the synthesis of nanoparticles and to the excitation of surface plasmon vibrations in metal nanoparticles (Mulvaney, 1996).

The UV-Vis absorption spectrum of the biosynthesized AgNPs of $U_{10}$ was obtained at $430 \mathrm{~nm}$ (Fig. 2). UV-Visible absorption spectroscopy has proven to be a versatile technique in the analysis of AgNPs (Sastry et al., 1997) and may provide information about morphology, size and stabilization of AgNPs (Kanmani and Lim, 2013).

The FTIR measurements were carried out to identify the possible biomolecules responsible for the stabilization of the synthesized AgNPs. The FTIR spectrum (Fig. 3) of the biosynthesized AgNPs showed peaks at 1,039; 1,242; 1,394; $1,4591,546 ; 1,6332,923$ and $3,354 \mathrm{~cm}^{-1}$. The peak at 3,354 $\mathrm{cm}^{-1}$ indicated the presence of primary amine (Shaligram $\mathrm{et} \mathrm{al.,}$ 2009), while the band at $1,546 \mathrm{~cm}^{-1}$ have been previously reported as a result of secondary amine (Vigneshwaran $e t a l$., 2007). The bands at 1,459 and $1,394 \mathrm{~cm}^{-1}$ are due to $\mathrm{C}=\mathrm{O}$ and hydroxyl group deformation responsible for the bio-reduction of silver metal ion to silver nanoparticles (Vigneshwaran et al., 2007; Philip, 2009; Thirumurugan et al., 2011; Gopinath and Velusamy, 2013), while bands at 1,242 and $1,039 \mathrm{~cm}^{-1}$ are due 
408

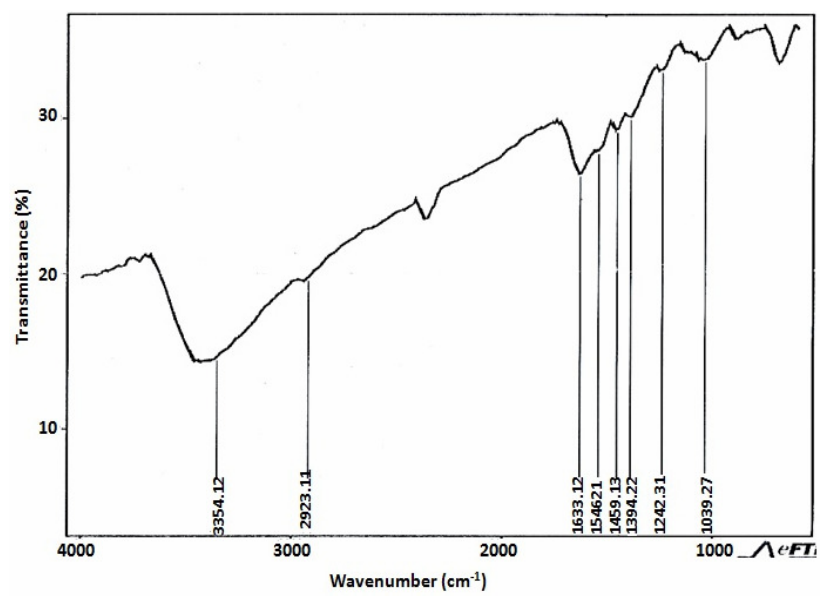

Fig. 3. FTIR spectrum of the biosynthesized AgNPs

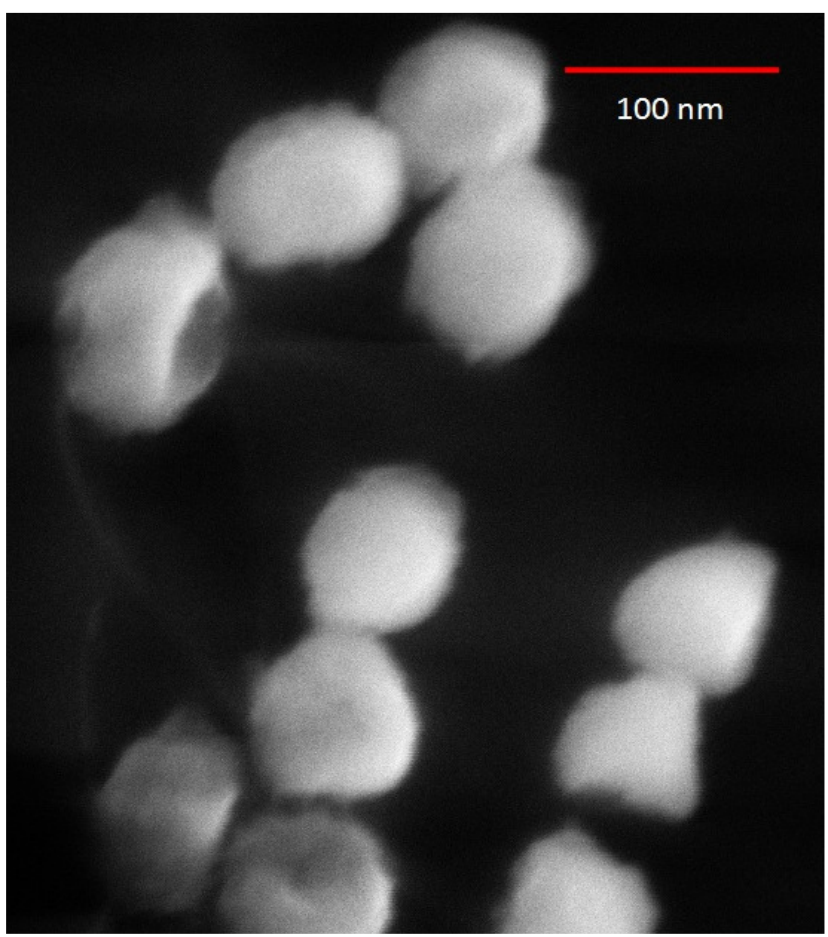

Fig. 4. Scanning electron micrograph of the biosynthesized AgNPs

to $\mathrm{OH}$ and aliphatic amine deformation (Philip, 2009; Gopinath and Velusamy, 2013). It has been reported that proteins can bind to nanoparticles through free amine groups or cysteine residues in the proteins (Gong et al., 2004), hence it can be inferred that these biomolecules of $L$. edodes were responsible for capping and stabilization of AgNPs. Thus far, this is the first report on the biosynthesis of AgNPs using the metabolite of $L$. edodes.

The scanning electron micrograph of AgNPs produced is shown in Fig. 4. The AgNPs were walnut-shaped and the size ranged between 50-100 nm. Spherical shaped AgNPs of varying sizes have been previously reported (Kannan et al., 2013; Lateef et al., 2015c). This study has therefore revealed the capability of laccase of $L$. edodes at forming nanoparticles, which may add to the growing applications of laccases and $L$. edodes.
Table 2. Antibacterial activity of the laccase biosynthesized AgNPs using $U V_{10}$ strain of $L$. edodes

\begin{tabular}{lc}
\hline Bacterial isolates & Zone of inhibition $(\mathrm{mm})$ \\
\hline E. coli $($ Strain A) & 15.0 \\
E. coli $($ Strain B) & - \\
E. coli (Strain C) & 20.0 \\
P. aeruginosa (Strain A) & 12.0 \\
P. aeruginosa (Strain B) & 14.0 \\
P. aeruginosa (Strain C) & - \\
K. pneumoniae (Strain A) & - \\
K. pneumoniae (Strain B) & 12.0 \\
K. pneumoniae (Strain C) & 11.0 \\
S. aureus & - \\
Percentage antimicrobial activity (\%) & 60 \\
\hline Strains A,BandCwereobtainedfrom urine, high viginal swabandwoundrespectively
\end{tabular}

\section{Antibacterial activities of the biosynthesized AgNPs}

The AgNPs showed selective antimicrobial activities against the ten clinical bacterial isolates tested. AgNPs synthesized induced a maximum inhibitory zone of $20 \mathrm{~mm}$ at a concentration of $141 \mu \mathrm{g} / \mathrm{ml}$ for $\mathrm{UV}_{10}$ AgNPs (Table 2). The efficacies of AgNPs have been reported against different strains of bacteria (Morones et al., 2005; Kim et al., 2007; Priyadarshini et al., 2013; Lateef et al., 2015a, c) and reported to have high surface to volume ratio, which enhanced antimicrobial activity as compared with bulk silver metal (Rai et al., 2009). The antibacterial activity has been reported to be size dependent (Bhat et al., 2011), while interaction between AgNPs, silver and phosphorus containing biomolecules of the bacterial cell may aid the entrance of the particles into the bacterial cell, thereby resulting in cell-killing through the attack of the respiratory chain and cell division. As indicated in Table 2, the $\mathrm{UV}_{10}$ AgNPs had an activity of $60 \%$ against total bacterial strains tested. Therefore, the appreciable antibacterial property demonstrated by the biosynthesized AgNPs has shown that it can be incorporated as antibacterial agent for some applications.

\section{Conclusions}

This study has led to the development of new strains of $L$. edodes with improved laccase production through physical mutation. The application of laccase of L. edodes in the green synthesis of AgNPs was demonstrated, leading to the formation of walnut-shaped AgNPs. The FTIR analysis revealed that proteins were responsible for the AgNPs formation with the AgNPs synthesized, demonstrating remarkable antimicrobial activity against clinical isolates of $E$. coli, $P$. aeruginosa and Klebsiella pneumoniae. Therefore, the technique presented in this study could be used in the development of novel fungal strain for application in the production of enzyme and green synthesis of nanoparticles for biotechnological applications.

\section{References}

Abadulla E, Tzanov T, Costa S, Robra K, Cavaco-Paulo A, Gübitz G (2000). Decolorization and detoxification of textile dyes with a laccase from Trametes hirsuta. Applied Environmental Microbiology 66:3357-3362. 
Abid JP, Wark AW, Brevet PF, Girault HH (2002). Preparation of silver nanoparticles in solution from a silver salt by laser irradiation. Chemical Communication 7:792-793.

Acosta E (2009). Bioavailability of nanoparticles in nutrient and nutraceutical delivery. Current Opinion in Colloid Interface Science 14:3-15.

Adebayo EA, Oloke JK, Achana Y, Bora T (2012). Improvement of laccase production in Pleurotus pulmonarius - LAU 09 by mutation. Journal of Microbiology 2:11-17.

Barros L, Cruz T, Baptista P, Estelvinho LM, Ferreira ICFR (2008). Wild and commercial mushrooms as source of nutrients and nutraceuticals. Food and Chemical Toxicology 46:2742-2747.

Bhat R, Deshpande R, Ganachari SV, Huh DO, Venkataraman A (2011). Photo-irradiated biosynthesis of silver nanoparticles using edible mushroom Pleurotus florida and their antibacterial activity. Bioinorganic Chemistry Applications 2011:650979.

Bisen PS, Baghel RK, Sanodiya BS, Thakur GS, Prasad GBKS (2010). Lentinus edodes: a macrofungus with pharmacological activities. Current Medicinal Chemistry 17:2419-2430.

Cavallazzi JRP, Brito MS, Oliveira MGA, Villas-Bôas SG, Kasuya MCM (2004). Lignocellulolytic enzymes profile of three Lentinula edodes (Berk.) Pegler strains during cultivation on eucalyptus bark-based medium. Food, Agriculture and Environment 2(1):291-297.

Claus H (2004). Laccases: structure, reactions, distribution. Micron 35(1):93-96.

Couto SR, Herrera JLT (2006). Industrial and biotechnological applications of laccases: a review. Biotechnology Advances 24:500-513.

Couto SR, Sanromán MA, Gübitz GM (2005). Influence of redox mediators and metal ions on synthetic acid dye decolourization by crude laccase from Trametes hirsuta. Chemosphere 58:417-422.

Dhakar K, Pandey A (2013). Laccase production from a temperature and $\mathrm{pH}$ tolerant fungal strain of Trametes hirsuta (MTCC 11397). Enzyme Research 2011:869062 (article ID).

Dubois M, Gilles K, Hamilton J, Rebers P, Smith F (1956). Colorimetric method for determination of sugar and related substances. Analytical Chemistry 28:350-356.

Durán M, Silveira CP, Durán N (2015). Catalytic role of traditional enzymes for biosynthesis of biogenic metallic nanoparticles: a mini-review. IET Nanobiotechnology DOI: 10.1049/ietnbt.2014.0054

Durán N, Cuevas R, Cordi L, Rubilar O, Diez MC (2014). Biogenic silver nanoparticles associated with silver chloride nanoparticles (Ag@ AgCl) produced by laccase from Trametes versicolor. SpringerPlus 3(1):645.

Duran N, Esposito E (2000). Potential applications of oxidative enzymes and phenoloxidase-like compounds in wastewater and soil treatment: a review. Applied Catalysis B: Environmental 28(2):83-99.

Duran N, Marcato PD, De S, Gabriel IH, Alves OL, Esposito E (2007). Antibacterial effect of silver nanoparticles produced by fungal process on textile fabrics and their effluent treatment. Journal of Biomedical Nanotechnology 3:203-208.
Durán N, Marcato PD, Alves OL, De Souza HIH, Esposito E (2005). Mechanistic aspects of biosynthesis of silver nanoparticles by several Fusarium oxysporum strains. Journal of Nanotechnology 3(8):1-7.

El-Batal AI, ElKenawy NM, Yassin AS Amin MA (2015). Laccase production by Pleurotus ostreatus and its application in synthesis of gold nanoparticles. Biotechnology Reports 5:31-39.

Ellis-Behnke RG, Liang YX, You SW, Tay DK, Zhang S, So KF, Schneider GE (2006). Nano neuro knitting: peptide nanofiber scaffold for brain repair and axon regeneration with functional return of vision. Proceedings of the National Academy of Sciences of the United States of America 103(13):5054-5059.

Faramarzi MA, Forootanfar H (2011). Biosynthesis and characterization of gold nanoparticles produced by laccase from Paraconiothyrium variabile. Colloids and Surfaces B: Biointerfaces 87:23-27.

Fernández-Fernández M, Sanromán MA, Moldes D (2013). Recent developments and applications of immobilized laccase. Biotechnology Advances 31:1808-1825.

Finimundy TC, Dillon AJP, Henriques JAP, Ely MR (2014). A review on general nutritional compounds and pharmacological properties of the Lentinula edodes mushroom. Food and Nutrition Science 5:1095-1105.

Fonseca MI, Fariña JI, Sanabria NI, Villalba LL, Zapata PD (2013). Influence of culture conditions on lacasse production, growth, and isoenzymes patterns in native white rot fungi from the misiones rainforest (Argentina). BioResources 8(2):2855-2866.

Gasaymeh SS, Radiman S, Lee YH, Saion E, Saeed GH (2010). Synthesis and characterization of silver/polyvinilpirrolidone (Ag/PVP) nanoparticles using gamma irradiation techniques. American Journal of Applied Sciences 7:892-901.

Gong P, Li H, He X, Wang K, Hu J, Tan W, Zhang S, Yang X (2007). Preparation and antibacterial activity of $\mathrm{Fe}_{3} \mathrm{O}_{4} \mathrm{Ag}$ nanoparticles. Journal of Nanotechnology 18:604-611.

Gopinath V, Velusamy P (2013). Extracellular biosynthesis of silver nanoparticles using Bacillus sp. GP-23 and evaluation of their antifungal activity towards Fusarium oxysporum. Spectrochimica Acta Part A: Molecular and Biomolecular Spectroscopy 106:170-174.

Gu H, Ho PL, Tong E, Wang L, Xu B (2003). Presenting vancomycin on nanoparticles to enhance antimicrobial activities. Nano Letters 3:1261-1263.

Guzman M, Dille J, Godet S(2012). Synthesis and antibacterial activity of silver nanoparticles against gram-positive and gramnegative bacteria. Nanomedicine: Nanotechnology, Biology and Medicine 8:37-45.

Harisinghani MG, Barentsz J, Hahn PF, Deserno WM, Tabatabaei S, van de Kaa CH, de la Rosette J, Weissleder R (2003). Noninvasive detection of clinically occult lymph-node metastases in prostate cancer. New England Journal of Medicine 19:2491-2499.

Hou H, Zhou J, Wang J, Du C, Yan B (2004). Enhancement of laccase production by Pleurotus ostreatus and its use for the decolorization of anthraquinone dye. Process Biochemistry 39(11):1415-1419.

Huang H, Yang X (2004). Synthesis of polysaccharide-stabilized gold 
410

and silver nanoparticles: a green method. Carbohydrate Research 339:2627-2631.

Kalimuthu K, Babu RS, Venkataraman D, Bilal M, Gurunathan S (2008). Biosynthesis of silver nanocrystals by Bacillus licheniformis. Colloids and Surfaces B: Biointerfaces 65:150153.

Kanmani P, Lim ST (2013). Synthesis and structural characterization of silver nanoparticles using bacterial exopolysaccharide and its antimicrobial activity against food and multidrug resistant pathogens. Process Biochemistry 48:10991106.

Kannan RRR, Arumugam R, Ramya D, Manivannan K, Anantharaman P (2013). Green synthesis of silver nanoparticles using marine macroalga Chaetomorpha linum. Applied Nanoscience 3:229-233.

Kim JS, Kuk E, Yu KN, Kim JH, Park SJ, Lee HJ, Kim SH, Park YK, Park YH, Hwang CY, Kim YK, Lee YS, Jeong DH, Cho $\mathrm{MH}$ (2007). Antimicrobial effects of silver nanoparticles. Nanomedicine: Nanotechnology, Biology and Medicine 3:95101.

Kneuer C, Sameti M, Bakowsky U, Schiestel T, Schirra H, Schmidt H, Lehr C (2000). A nonviral DNA delivery system based on surface modified silica-nanoparticles can efficiently transfect cells in vitro. Bioconjugate Chemistry 11:926-932.

Kuhad RC, Singh A, Eriksson KEL (1997). Microorganisms and enzymes involved in the degradation of plant fibre cell walls. Biotechnology in the pulp and paper industry. Springer Berlin Heidelberg pp 45-125

Kumar A, Vemula PK, Ajayan PM, John G (2008). Silvernanoparticle-embedder antimicrobial paints based on vegetable oil. Nature Materials 7:236-241.

Kumar GN, Srikumar K (2011). Thermophilic laccase from xerophyte species Opuntia vulgaris. Biomedical Chromatography 25(6):707-711.

Lara HH, Ayala-Núnez NV, Turrent LDCI, Padilla CR (2010). Bactericidal effect of silver nanoparticles against multidrugresistant bacteria. World Journal of Microbiology and Biotechnology 26:615-621.

Lateef A, Adelere IA, Gueguim-Kana EB, Asafa TB, Beukes LS (2015a). Green synthesis of silver nanoparticles using keratinase obtained from a strain of Bacillus safensis LAU 13. International Nano Letters 5:29-35.

Lateef A, Azeez MA, Asafa TB, Yekeen TA, Akinboro A, Oladipo IC, ... Beukes LS (2015b). Cola nitida-Mediated Biogenic Synthesis of Silver Nanoparticles Using Seed and Seed Shell Extracts and Evaluation of Antibacterial Activities. BioNanoScience 5(4):196-205.

Lateef A, Ojo SA, Akinwale AS, Azeez L, Gueguim-Kana EB, Beukes LS (2015c). Biogenic synthesis of silver nanoparticles using cell-free extract of Bacillus safensis LAU 13: antimicrobial, free radical scavenging and larvicidal activities. Biologia 70 (10):1295-1306.

Leonowicz A, Cho N, Luterek J, Wilkolazka A, Wojtas-Wasilewska M, Matuszeska A, Hofrichter M, Wesnberg D, Rogalski J
(2001). Fungal laccase: properties and activity on lignin. Journal of Basic Microbiology 41:185-227.

Lloyd JR (2003). Microbial reduction of metals and radionuclides. FEMS Microbiology Reviews 27:411-425.

Makkar RS, Tsuneda A, Tokuyasu K, Mori Y (2001). Lentinula edodes produces a multicomponent protein complex containing manganese (II) dependent peroxidase, laccase and $\beta$-glucosidase. FEMS Microbiology Letters 200:175-179.

Martin CR, Kohli P (2003). The emerging field of nanotube biotechnology. Nature Review Drug Discovery 2:29-37.

Mohamed AGT (2013). Stachybotrys chartarum: a novel biological agent for the extracellular synthesis of silver nanoparticles and their antimicrobial activity. Indonesian Journal of Biotechnology 18:75-82.

Morones JR, Elechiguerra JL, Camacho A, Holt K, Kouri JB, Ramírez JT, Yacaman MJ (2005). The bactericidal effect of silver nanoparticles. Nanotechnology 16:2346-2353.

Morozova OV, Shumakovich GP, Shleev SV, Yaropolov YI (2007). Laccase-mediator systems and their applications: a review. Applied Biochemistry and Microbiology 43:523-535.

Mukherjee P, Senapati S, Mandal D, Ahmad A, Khan M, Kumar R, Sastry M (2002). Extracellular synthesis of gold nanoparticles by the fungus Fusarium oxysporum. ChemBioChem 3(5):461-463.

Mulvaney P (1996). Surface plasmon spectroscopy of nanosized metal particles. Langmuir 12:788-800.

Nehad EA, El-Shamy AR (2010). Physiological studies on the production of exopolysaccharide by fungi. Agriculture and Biology Journal of North America 1:1303-1308.

Philip D (2009). Biosynthesis of Au, Ag and Au-Ag nanoparticles using edible mushroom extract. Spectrochimica Acta Part A: Molecular and Biomolecular Spectroscopy 73:374-381.

Priyadarshini S, Gopinath V, Priyadarshini NM, Ali D, Velusamy P (2013). Synthesis of anisotropic silver nanoparticles using novel strain, Bacillus flexus and its biomedical application. Colloids and Surfaces B: Biointerfaces 102:232-237.

Rai M, Yadav A, Bridge P, Gade A (2009). Myconanotechnology: a new and emerging science. Applied Mycology 14:258-267.

Rai M, Yadav A, Gade A (2009). Silver nanoparticles as a new generation of antimicrobials. Biotechnology Advances 27:7683.

Ride JP (1980). The effect of induced lignification on the resistance of wheat cell walls to fungal degradation. Physiological Plant Pathology 16:187-196.

Sanghi R, Verma P (2009). Biomimetic synthesis and characterisation of protein capped silver nanoparticles Bioresource Technology 100(1):501-504.

Sanghi R, Verma P, Puri S (2011). Enzymatic formation of gold nanoparticles using Phanerochaete chrysosporium. Advances in Chemical Engeneering and Science 1(3):154.

Sastry M, Mayya KS, Patil V, Paranjape DV, Hegde SG (1997). Langmuir-Blodgett films of carboxylic acid derivatized silver colloidal particles: role of subphase $\mathrm{pH}$ on degree of cluster incorporation. The Journal of Physical Chemistry B 101(25):4954-4958. 
Schabes-Retchkiman PS, Canizal G, Herrera-Becerra R, Tripathy A, Chandrasekaran N, Raichur AM, Mukherjee A Zorrilla C, Liu HB, Ascencio JA (2006). Biosynthesis and characterization of $\mathrm{Ti} / \mathrm{Ni}$ bimetallic nanoparticles. Optical Materials 29:95-99.

Shaligram N, Singh S, Singhal R, Szakacs G, Pandey A (2009). Effect of precultural and nutritional parameters on compactin production by solid state fermentation. Journal of Microbiology and Biotechnology 19:690-697.

Strong PJ (2011). Improved laccase production by Trametes pubescens MB89 in distillery wastewaters. Enzyme Research DOI: $10.4061 / 2011 / 379176$

Thillaimaharani K, Sharmila K, Thangaraju P, Karthick M, Kalaiselvam M (2013). Studies on antimicrobial and antioxidant properties of oyster mushroom Pleurotus florida. International Journal Pharmaceutical Science Research 4:1540-1545.

Thirumurugan A, Tomy NA, Kumar HP, Prakash P (2011). Biological synthesis of silver nanoparticles by Lantana camara leaf extracts. Int J Nanomater Bioresource 1:22-24.

Toh-e AKIO, Wickner RB (1981). Curing of the $2 \mu$ DNA plasmid from Saccharomyces cerevisiae. Journal of Bacteriology 145:1421-1424. (2010). Process variables in biomimetic synthesis of silver nanoparticles by aqueous extract of Azadirachta indica (Neem) leaves. Journal of Nanoparticle Research 5:93-98.

Uhrich K, Cannizzaro S, Langer R, Shakeshelf K (1999). Polymeric systems for controlled drug release. Chemical Reviews 99:3181-3198.

Vetchinkina EP, Loshchinina EA, Burov AM, Dykman LA, Nikitina VE (2014). Enzymatic formation of gold nanoparticles by submerged culture of the basidiomycete Lentinus edodes. Journal of Biotechnology 182:37-45.

Vetchinkina EP, Burov AM, Ageeva MV, Dykman LA, Nikitina VE (2013). Biological synthesis of gold nanoparticles by the xylotrophic basidiomycete Lentinula edodes. Applied Biochemistry Microbiology 49:406-411.

Vigneshwaran N, Ashtaputre N, Varadarajan P, Nachane R, Paralikar K, Balasubramanya R (2007). Biological synthesis of silver nanoparticles using the fungus Aspergillus flavus. Material Letters 61:1413-1418. 